\title{
DEGRADASI PUITIKA DALAM KONTESTASI LITERASI CERITA KKN DI DESA PENARI
}

\author{
Muhammad Lutfi Dwi Kurniawan¹, Hadi Prasetyo², Aditya Wicaksono³, Fian Ulumul Akmal ${ }^{4}$ \\ Magister Ilmu Sastra ${ }^{1,2}$, Magister Linguistik ${ }^{3}$, Bahasa dan Sastra Indonesia ${ }^{4}$ UGM \\ mulutdk@mail.ugm.ac.id¹, prasetyo4tawa@gmail.com², \\ adityawicak88@gmail.com ${ }^{3}$, overvayne@gmail.com ${ }^{4}$
}

\begin{abstract}
Abstrak
Cerita KKN di Desa Penari merupakan sebuah sastra siber yang populer karya Simpleman dengan genre horor. Kepopuleran tersebut tidak terlepas dari strategi puitika dan pengaruh media yang digunakan. Dalam cerita horor KKN di Desa Penari, strategi puitika akan ditinjau dari kepenuhperistiwaan cerita yang membentuk sensitivitas-konteks di dalam teks, sedangkan pengaruh media akan dilihat dari transformasi sastra siber ke sastra cetak yang berimplikasi pada konsekuensi-konsekuensi teks dalam tatanan literasi. Melalui hal tersebut, penelitian ini bertujuan menganalisis strategi puitika sebagai pembangunan eventfulness dan melihat praktik transformasi media yang berimbas pada intensitas puitika. Adapun temuan penelitian ini adalah sebagai berikut. Pertama, sebagai cerita horor, KKN di Desa Penari menawarkan beberapa strategi puitika dalam meleburkan paradigma fiksi dan fakta. Hal tersebut dicapai melalui evaluative device, berupa refleksi karakter, repetisi peristiwa, dan disnarasi yang menciptakan eventfulness sehingga terbentuk sensitivitas-konteks. Kedua, praktik transformasi media mengakibatkan perubahan bentuk teks dari nonliterasi menuju literasi. Melalui hal tersebut, cerita horor $K K N d i$ Desa Penari menerima konsekuensi berupa formalisasi bahasa karena standardisasi media. Selain itu, keterlibatan cerita horor KKN di Desa Penari ke dalam zona literasi merupakan kendali kekuasaan dari agenda kapitalisme dalam bentuk print-capitalism. Dengan demikian, dapat ditarik muara analisis bahwa cerita horor KKN di Desa Penari yang terlibat ke dalam zona literasi justru dihadapkan pada degradasi puitika.
\end{abstract}

Kata Kunci: horor, literasi, puitika, transformasi media

\begin{abstract}
The story of KKN di Desa Penari is a popular cyber literacy by Simpleman which horror genre. It popularity can't be separated from poetics and media that used. The story of KKN di Desa Penari's poetical strategy will be seen from eventfulness that shapes context-sensitivity on the text, at the same time, media will be seen as a transformation from cyber literacy into print-literacy that has implified the text consequences from the construction of literacy. Through that, this research aims to analyze the poetical strategy as an eventfulness development and see the practice of media transformation which has an impact on poetical intensity. The discovery of this research is as follows. First, as a horror story, KKN di Desa Penari offer a few poetical strategy to immersed fictional and factual paradigm. This was achieved through evaluative device, that is character reflection, repetition of events, and the disnarrative that creates eventfulness thus developing context-sensitivity. Second, the practice of media transformation inflict the transliteration of text from nonliteration to literacy. Through this, the horror story of KKN di Desa Penari received the consequence of formalization of language inflicted by media standardization. Moreover, the involvement the horror story of KKN di Desa Penari into the literacy zone was a power control over the capitalism agenda in the form of print-capitalism. Therefore, this analysis comes down the horror story of KKN di Desa Penari that was involved in the literacy zone was exposed to poetical degradation.
\end{abstract}

Keywords: horror, literacy, poetics, media transformation 
Poetika: Jurnal Ilmu Sastra

Vol. VII No. 2, Desember 2019
DOI 10.22146/poetika.51571

ISSN 2338-5383 (print); 2503-4642 (online)

\section{Pendahuluan}

Cerita KKN di Desa Penari (kemudian disebut KDDP) merupakan salah satu kisah horor yang pertama kali disebarluaskan di media sosial twitter oleh akun @SimpleM813785231 atau yang lebih dikenal Simpleman. Melalui hal tersebut, cerita KDDP dapat digolongkan sebagai karya sastra siber karena pertama kali hadir melalui media sosial twitter ${ }^{2}$. Cerita KDDP pada awalnya dibuat dalam bentuk thread twitter yang pertama kali ditampilkan pada tanggal 24 Juni 2019. Ada dua versi cerita yang diungkapkan melalui dua sudut pandang berbeda, yakni versi Widya dan versi Nur. Cerita versi Widya ditulis dan dipublikasikan dalam rentang waktu 24 Juni 2019 sampai 5 Juli 2019, sedangkan cerita versi Nur ditulis dan dipublikasikan dalam rentang waktu 20 Juli 2019 sampai 25 Juli 2019. Thread twitter KDDP menjadi karya populer pada saat itu yang dibuktikan dengan jumlah retweet yang mencapai 49.000 lebih, jumlah like mencapai 132.000 lebih, dan jumlah komentar mencapai 5.200 lebih. Kepopuleran thread twitter KDDP menarik perhatian masyarakat untuk mengulas kembali cerita tersebut melalui media-media yang berbeda, seperti podcast, youtube, facebook, artikel, dan buku novel cetak. $^{3}$

Secara garis besar, KDDP berkisah tentang pengalaman mahasiswa yang sedang berkegiatan $\mathrm{KKN}^{4}$ di sebuah desa yang berinisial Desa W. Dalam menjalani kegiatan tersebut, enam tokoh cerita yang bernama Nur, Ayu, Widya, Bima, Wahyu, dan Anton mengalami berbagai kejadian mistis. Kejadi- an itu berawal dari dua tokoh yang mendengar suara gamelan di sebuah hutan saat melakukan perjalanan menuju desa tempat mereka KKN. Kejadian-kejadian mistis semakin berdatangan ketika mereka memasuki Desa W, mulai dari nisan yang ditutup kain hitam, suara sinden di kamar mandi, bingkisan makanan yang berubah menjadi kepala monyet, hingga kemunculan penari dengan selendang hijau pada saat tengah malam. Kejadian-kejadian mistis tersebut menggiring tokoh-tokohnya untuk mengungkap misteri di Desa W. Misteri dari kejadian-kejadian di Desa W yang dialami para tokohnya dipantik oleh dua tokoh, Bima dan Ayu, yang melanggar aturan desa, yakni melakukan persenggamaan. Hal tersebut memicu kemarahan sinden yang menunggu hutan di Desa W sehingga mengakibatkan kematian tokoh Bima dan Ayu.

Kisah KDDP tersebut kemudian dianggap sebagai karya sastra populer karena menuai banyak tanggapan dari pengguna media sosial, khususnya twitter. Kepopuleran cerita KDDP di media sosial twitter juga berimbas pada reproduksinya melalui media lain. Hal tersebut disebabkan oleh puitika gaya bahasa lisan yang digunakan sehingga mengundang partisipasi aktif pembaca melalui komentar di berbagai media sosial. Atensi tersebut mengakibatkan cerita KDDP menjadi viral dan populer. Mengutip pernyataan dari Williams:

Popular culture was not identified by the people but by others, and it still carries two older senses: inferior kinds of work (cf. popular literature, popular press as distinguished from quality press); and work deliberately setting out to win favour (popular journalism as distinguished from democratic journalism, or popular entertainment); as well as the more modern sense of well-liked by many people, with which of course, in many cases, the earlier senses overlap (Williams, 1985: 237). 
Dari kutipan tersebut, populer bersifat kuantitas, objektif, dan masif. ${ }^{5}$ Populer menurut Williams memiliki empat makna; hal yang disukai banyak orang, jenis hal yang dianggap rendah, hal yang dengan sengaja diatur untuk memenangkan selera banyak orang, dan sebuah budaya yang dibuat dari masyarakat untuk masyarakat. Oleh karena itu, kemunculan cerita KDDP memanfaatkan elemen-elemen dalam kepentingan mendapatkan atensi. Elemen-elemen tersebut dibagi menjadi dua bagian, yaitu elemen internal dan elemen eksternal teks. Elemen internal mencakup unsur-unsur puitika di dalam teks sehingga cerita $K D D P$ mampu membenamkan pembaca pada dunia yang dibangun. Elemen eksternal mencakup konstruksi sosial di dalam teks yang berkaitan dengan media berbasis internet. Dalam konstruksi sosial, internet merupakan sebuah sistem diskursif yang memberi fasilitas untuk mengidentifikasi negosiasi antara makna dan identitas, mengembangkan hubungan dalam komunitas, dan menemukan konstruksi sosial secara diskursif. ${ }^{6}$ Kolaborasi antarelemen itu menunjang kepopuleran KDDP sehingga mengundang atensi besar dari pembaca.

Cerita KDDP merupakan karya sastra bergenre horor. Secara umum, efektivitas monster dalam teks horor secara jelas didemonstrasikan $^{7}$ di dalam peristiwa yang mengerikan atau pertemuan dengan manusia yang bersifat demoralisasi (Carroll, 1990: 141). Sebagai karya sastra bergenre horor, cerita $K D D P$ memuat peristiwa-peristiwa mistis yang dihadapkan pada kehidupan nyata para tokohnya dalam melakukan KKN di Desa W.
Narasi tersebut menunjukkan dunia yang dihadirkan secara bersamaan. Hal tersebut pada akhirnya merujuk pada merging realism atau alam yang bercampur untuk menyatukan hal yang natural dan supernatural; magis dan real (Faris, 2004: 7). Hal-hal yang berkaitan dengan hidup dan mati, nyata dan khayal, dan seterusnya berusaha dileburkan dan disatukan (Faris dan Zamora, 1995: 6). Dalam hal ini, cerita KDDP tampak berusaha meleburkan dan menyatukan hal-hal tersebut sebagai upaya menciptakan eventfulness cerita.

Selain itu, narasi KDDP memunculkan objek hantu sebagai unsur sentral dalam pembangunan alur cerita. Menurut Brummer (2016: 167), kemunculan objek hantu menimbulkan antisipasi, reaksi, dan pada akhirnya ditentang oleh para tokoh di dalam teks. Sastra horor tidak hanya berkisar pada penampilan hantu dalam cerita itu, tetapi juga pada peristiwa yang melingkupi kemunculan hantu tersebut. Brummer (2016: 167) menambahkan bahwa terdapat dua level yang menentukan keberhasilan sastra horor, antara lain; (1) penyajian tentang hantu yang menarik dan meyakinkan, yang dinilai terutama oleh standar ontologi fiksi dan (2) memancing reaksi emosional pembaca yang bersumber dari luar dunia teks fiksi. Penyajian objek hantu tersebut berkaitan dengan peristiwa yang melingkupinya. Dalam hal ini, Prince (2008) menyebutkan terdapat tiga komponen evaluative devices, yaitu refleksi karakter, repetisi peristiwa, dan disnarasi dalam memunculkan hantu sehingga menjadi sebuah peristiwa yang eventfulness atau kepenuhperistiwaan.

Dengan demikian, dapat dipahami bahwa 
cerita $K D D P$ sebagai sastra bergenre horor berusaha mengatasi kesenjangan antara ekspektasi pembaca pada penyajian hantu dengan narasi yang diberikan oleh teks. Dalam hal ini, kesenjangan itulah yang menjadi strategi puitika dalam merebut atensi pembaca.

Selain strategi puitika dalam sastra horor tersebut, cerita KDDP memanfaatkan multisiplitas media dalam memproduksi sekaligus memopulerkan teks. Menurut Kittler (1986: 157), konsep media dapat dipahami sebagai kebutuhan manusia dalam mengembangkan perbendaharaan konseptual pada kaitannya dengan teknologi dan cara mempresentasikan pengalaman manusia. Sementara itu, McLuhan (1967: 40-41) melihat media sebagai perwakilan dari lingkungan untuk membangkitkan anggapan unik dari persepsi rasa. Dalam kaitannya terhadap cerita $K D D P$, media yang digunakan untuk memproduksi cerita tidak bersifat tunggal. Sebagai produsen cerita, Simpleman mentransformasikan cerita $K D D P$ dari media twitter ke media cetak. Hal tersebut akan dilihat sebagai sebuah pergerakan dari nonliterasi menuju literasi. Ketika cerita KDDP bertransformasi ke media cetak atau literasi, ada beberapa konsekuensi yang didapatkan. Konsekuensi tersebut menyebabkan masuknya cerita $K D D P$ dalam pusaran nasionalisme sebagai selubung dari industri kapitalisme modern sehingga berdampak pada intensitas puitika dan konstruksi identitas. Dari uraian di atas, transformasi media dalam KDDP juga berdampak pada transformasi puitika dan identitas.
Berdasarkan latar belakang yang telah dikemukakan di atas, permasalahan dalam penelitian ini adalah mengungkap strategi puitika sebagai konstruksi eventfulness dan menyelisik konsekuensi-konsekuensi cerita KDDP di dalam tatanan literasi sebagai akibat dari transformasi media.

\section{Sensitivitas-Konteks dan Puitika Pem- benaman dalam Cerita KKN di Desa Penari}

Kepopuleran cerita KKN di Desa Penari $(K D D P)$ tidak terlepas dari puitika sastra horor. Puitika tersebut menjadi kemampuan naratif (narratability) dalam menenggelamkan pembaca ke dalam dunia fiksi. Puitika pembenaman (poetic of immersion) mencoba melihat puitika sebagai transportasi pembaca untuk memasuki dunia fiksi dalam teks. Mengutip pernyataan Hogan:

Through the interaction of the text and the imagination of the readers, guided by the principal of minimal departure, the story world that readers are transported to is based on a combination of the text and their own ideas, experiences, and schemata that they project into the world on the basis of the "presumed identity" of the storyworld and their own world (Hogan, 2013: 62-63).

Transportasi tersebut menjadi alat dalam peleburan dunia pembaca ke dalam dunia fiksi. Dalam kaitannya pada sastra horor, poetic of immersion berkaitan erat pada kemunculan hantu pada sebuah peristiwa. Kengerian, kemistisan, atau suasana horor di dalam teks bukan bersumber dari fitur-fitur hantu yang menyebabkannya menjadi unnatural, melainkan melalui proses refleksi dari bagaimana peristiwa tersebut merespons ketidaknaturalan objek hantu. Prince mengatakan:

The importance of an event in a text can be fore- 
Poetika: Jurnal Ilmu Sastra

Vol. VII No. 2, Desember 2019

grounded through "evaluative devices." These include the reflections of characters, the repetition of events, and the "use of disnarrated eventsexplicitly referring to what did not take place but could have," in order to underscore, foreground, or emphasize certain aspects of the narrative.(Prince, 2008: 23-24).

Proses perjumpaan tersebut merupakan sebuah eventfulness atau kepenuhperistiwaan yang kemudian menjadi sensitivitaskonteks antara pembaca dengan narasi fiksi. Eventfulness dapat dilihat melalui evaluative device yang berupa refleksi dari karakter, repetisi dari peristiwa, dan disnarasi dalam teks.

Dalam kaitannya pada teks KDDP, evaluative device akan digunakan untuk melihat bagaimana pembentukan eventfulness menjadi aspek keterbenaman pembaca dalam teks. Tenggelamnya pembaca tersebut juga akan dikaitkan dengan kondisi lokal dalam teks $K D D P$ yang berbentuk norma-norma, nilai-nilai, dan dialek. Implikasi dari kesemuanya merupakan tinjauan dari fungsi poetic of immersion dalam menciptakan sensitivitas-konteks.

\section{Evaluative Devices}

Evaluative devices berorientasi pada peristiwa-peristiwa yang membantu dalam proses keterbenaman pembaca ke dalam teks. Dalam cerita $K D D P$, terdapat tiga tokoh berbeda dalam merefleksikan salah satu peristiwa dalam teks, yakni ketika mereka mendengar suara gamelan pada saat perjalanan menuju lokasi KKN. Perhatikan kutipan cerita berikut ini.

(1) Di dalam kamar, Widya pun bertanya, maksud ucapanya kepada pak Prabu, karena sepanjang
DOI 10.22146/poetika.51571

ISSN 2338-5383 (print); 2503-4642 (online)

perjalanan, bila di rasakan oleh Widya sendiri, itu lebih dari satu jam, Ayu membantah bahwa lama perjalanan tidak sampai selama itu, anehnya, Nur memilih tidak ikut berdebat. Nur, lebih memilih untuk diam. "ngene, awakmu krungu ora, nang dalan alas mau, onok suara gamelan?" (gini, kamu dengar apa tidak, di jalan tadi, ada suara orang memainkan gamelan?)"yo paling onok hajatan lah, opo maneh" (ya palingan ada warga yang mengadakan hajatan, apalagi), berbeda dengan Ayu, Nur menatap Widya dengan ngeri.

(2) Saat itu, Nur mengatakanya. "Mbak, aku yo krungu suara gamelan iku" (Mbak, aku juga dengar suara gamelan itu) katanya. "masalahe mbak, aku yo ndelok onok penari'ne nang dalan mau" (masalahnya, aku juga lihat ada yang menari di jalan tadi).

(Thread Twitter KDDP, 2019)

Tiga tokoh, yakni Nur, Widya, dan Ayu mempunyai refleksi yang berbeda atas peristiwa terdengarnya suara gamelan pada saat perjalanan menuju lokasi KKN. Pada kutipan (1), tokoh Widya merasakan sebuah keganjilan pada suara gamelan yang didengarnya. Sementara itu, Ayu merespons peristiwa asing tersebut dengan sebuah penjelasan untuk menaturalisasi peristiwa. Akan tetapi, respons Ayu tersebut semakin membuat peristiwa menjadi asing dan unnatural. Pada kutipan (2), tokoh Nur merespons dengan diam pada awalnya, kemudian mengafirmasi apa yang dikatakan oleh tokoh Widya sehingga semakin memperkuat keganjilan tersebut. Perbedaan refleksi atas peristiwa terdengarnya suara gamelan dari tokoh-tokoh tersebut memberikan informasi mengenai hal mistis sehingga pembaca seakanakan ikut merasakan hal mistis. Peristiwa terdengarnya suara gamelan pada teks menjadi eventfulness ketika refleksi dari karakter dapat membuat pembaca terbenam akan cerita tersebut. Keterbenaman pembaca itulah yang menjadikan hal mistis menjadi sensitivitas-konteks 
Poetika: Jurnal Ilmu Sastra

Vol. VII No. 2, Desember 2019
DOI 10.22146/poetika.51571

ISSN 2338-5383 (print); 2503-4642 (online) cerita $K D D P$.

Gambaran hal mistis yang menjadi sensitivitas-konteks dalam cerita KDDP diperkuat lagi oleh perbedaan refleksi karakter atas sebuah peristiwa saat melihat sosok penari. Hal tersebut dapat dilihat melalui kutipan berikut.

(3) Wahyu. jarene ndelok Widya nari nang kene. mboh lapo, aku yo kaget pas ndelok, gak onok Widya nang kamar" (Wahyu, bilang, melihat Widya sedang menari disini, entahlah kok bisa, aku juga kaget waktu melihat Widya tidak ada di dalam kamar)".

(4) Malam itu sangat gelap, lebih gelap dari perkiraan Widya, bayangan pohon tampak lebih besar dari biasanya, dan sayup-sayup terdengar suara binatang malam, sangat sunyi, sangat sepi, di lihatnya kesana-kemari mencari dimana keberadaan Nur, Widya terpaku melihat Nur, di depannya, Nur berdiri di tanah lapang depan rumah, dia menari dengan sangat anggun, tanpa alas kaki, Nur berlenggak-lenggok layaknya penari professional.

(Thread Twitter KDDP, 2019)

Tokoh Wahyu pada kutipan (3) melihat bahwa sosok penari adalah tokoh Widya, tetapi tokoh Widya pada kutipan (4) justru melihat bahwa sosok penari itu adalah tokoh Nur. Dalam hal ini, perbedaan refleksi antartokoh atas peristiwa tersebut memunculkan sebuah pertanyaan tentang siapa yang sebenarnya menari. Ketidaktahuan tentang siapa yang sebenarnya menari membuat peristiwa tersebut menjadi eventfulness. Dalam hal ini, eventfulness yang terealisasikan melalui refleksi tokoh Wahyu, Widya, dan Nur membuat pembaca terbenam ke dalam dunia mistis atas peristiwa menari.

Refleksi-refleksi antartokoh dalam menjelaskan peristiwa ganjil di atas justru semakin mengukuhkan keganjilan. Keganjilan tersebut bersumber dari multirefleksi yang merekonstruksi alienasi tokoh pada suatu peristiwa. Dalam hal ini, rekonstruksi tersebut merupakan kesalahkiraan subjek pada objek yang ganjil. Keganjilan tersebut berkaitan dengan familiaritas tokoh-tokoh pada sebuah peristiwa. Ketika suatu objek tidak familiar bagi subjek, ia akan menimbulkan rasa cemas dan tidak nyaman. Objek ganjil yang tidak familiar, adalah objek yang kehilangan maknanya di depan subjek. Dengan demikian, melalui refleksirefleksi tokoh, eventfulness merupakan identifikasi tokoh terhadap peristiwa yang ganjil.

Selain refleksi tokoh yang telah dijelaskan di atas, repetisi peristiwa cerita $K D D P$ juga berperan penting dalam pembentukan eventfulness. Repetisi peristiwa yang paling sering muncul dalam cerita $K D D P$ ialah peristiwa menari. Dalam cerita $K D D P$, peristiwa menari terjadi pada latar yang berbeda-beda. Pada awal cerita, peristiwa bertemu dengan sosok penari terjadi di jalan menuju desa KKN. Setelah itu, peristiwa tersebut banyak dimunculkan lagi dalam cerita yang berlatar di sekitar tempat inap mahasiswa KKN di desa tersebut. Dalam hal ini, repetisi peristiwa dalam cerita KDDP menunjukkan sebuah progres. Progres narasi dalam repetisi peristiwa dalam cerita KDDP dapat dilihat melalui kutipan berikut.

(5) masalahe mbak, aku yo ndelok onok penari'ne nang dalan mau" (masalahnya, aku juga lihat ada yang menari di jalan tadi)

(6) Nur berdiri di tanah lapang depan rumah, dia menari dengan sangat anggun, tanpa alas kaki, Nur berlenggak-lenggok layaknya penari professional.

(7) Widya melihat Wahyu yang menatapnya dengan tatapan bingung plus takut."bengi bengi lapo As* nari -nari gak jelas nang kene!!" (malam-malam ngapain anji*g!! nari sendirian- disini seorang diri).

(8) Apapun itu, Widya sudah mengerti satu hal, ada hubungan yang secara tidak langsung, tentang dirinya dan sang Penari.

(9) Widya melihat, di depanya, ada yang sedang 
menari, tarianya hampir membuat semua yang ada disana melihatnya. disana, Widya menyadari, yang menari itu Ayu,

(10) Ayu sak iki, kudu nari, keliling Alas iki (Ayu sekarang harus menari mengelilingi Hutan ini)"

(11) Badarawuhi, iku salah sijine sing jogo wilayah iki, tugas Badarawuhi iku nari, dadi bangsa lelembut iku yo seneng ndelok Badarawuhi iki nari, nah, sak iki, Ayu kudu nanggung tugas Badarawuhi nari" (Badarawuhi itu salah satunya yang jaga di wilayah ini, tugasnya ya menari, jadi bangsa lelembut suka melihat tarian dari Badarawuhi, sekarang, Ayu harus menggantikanya).

(Thread Twitter KDDP, 2019)

Peristiwa menari tersebut menjadi sebuah peristiwa yang mengalami progres dengan cara mengaitkan repetisi dan konteks yang melingkupinya. Dalam kutipan (5) tergambar bagaimana objek hantu menjadi bagian yang berada di luar tokoh. Kutipan tersebut menunjukkan bagaimana peristiwa menari itu berada di tempat yang tidak tepat, yaitu jalan, sehingga menyebabkan alienasi pada tokoh-tokoh yang melihatnya. Alienasi tersebut berkembang menjadi alterisasi dari tokoh ketika objek hantu melakukan penubuhan terhadapnya. Penubuhan tersebut mengakibatkan penyempitan jarak antara yang unnatural dengan natural seperti pada kutipan (6), (7), dan (9). Dari proses alterisasi tersebut, salah satu tokoh, yaitu Widya, mengalami interkoneksi dengan objek hantu untuk mengurai peristiwa unnatural dalam kutipan (8). Kemudian, interkoneksi tersebut mengantarkan tokoh pada rekonfigurasi hantu dalam kutipan (10) dan (11) sehingga objek hantu dapat terindentifikasi.

Repetisi peristiwa menari dalam cerita $K D D P$ tersebut merupakan sebuah kesatuan dari rekonstruksi eventfulness yang dinarasikan melalui progres dari kesenjangan antara tokoh dengan objek hantu. Progres tersebut berupa alienasi, alterisasi, interkoneksi, dan identifikasi. Alienasi dalam teks membuat tokoh-tokohnya mengalami sebuah peristiwaperistiwa yang unnatural dan berjarak. Alienasi dalam teks merupakan pengenalan pada tokohtokoh terhadap sesuatu yang berada di luar pengetahuannya sehingga objek hantu menjadi objek yang unnatural berdasarkan kemunculan dan peristiwa yang melingkupinya. Sementara itu, alterisasi merupakan proses penyempitan jarak antara objek hantu dengan tokoh.

Dalam alterisasi tersebut, penubuhan objek hantu terhadap tokoh menciptakan sebuah alter ego yang mengubah posisi hantu sebagai objek menuju hantu sebagai subjek. Proses subjektivasi hantu membuat posisinya setara di hadapan tokoh-tokoh sehingga hantu diberikan ruang untuk bersuara dalam proses naturalisasinya. Suara dari subjek hantu membuat tokoh-tokohnya mengalami interkoneksi sehingga tokoh dapat mengakses rekonfigurasi hantu secara langsung. Setelah proses tersebut, hantu dapat teridentifikasi dari objek unnatural menjadi subjek yang natural. Dari repetisi peristiwa yang mengalami progres tersebut dapat dilihat bahwa eventfulness merupakan sebuah kesatuan rangkaian peristiwa dalam menaturalisasikan objek hantu menjadi subjek hantu.

Sementara itu, alat lain yang dapat digunakan untuk membentuk eventfulness dalam cerita $K D D P$ ialah disnarasi. Disnarasi dipahami sebagai strategi penceritaan peristiwa yang sengaja disembunyikan sehingga pembaca tidak diberikan uraian jelas mengenai peristiwa -peristiwa tertentu. Dalam hal ini, pembaca hanya dapat memperoleh wawasan tentang apa yang terjadi melalui upaya mereka membaca 
"pikiran yang tidak terbaca". Pembaca kemudian membenamkan dirinya pada teks untuk mengalami ketidaktahuan tokoh pada peristiwa yang terjadi sehingga menjembatani kesenjangan antara ontologi dunia fiksi dengan ontologi dunia pembaca.

Dalam cerita KDDP, terdapat beberapa disnarasi yang menunjukkan eventfulness. Disnarasi tersebut berbentuk pada peristiwaperistiwa yang seolah-olah dirahasiakan atau disembunyikan, seperti kutipan berikut.

(12) kemudian, sampailah di titik paling menakutkan "Tipak talas" kalau kata pak Prabu. sebuah batas dimana rombongan anak-anak di larang keras melintasi sebuah setapak jalan yang di buat serampangan, di kiri kanan, ada kain merah lengkap di ikat oleh janur kuning layaknya pernikahan.

"kenapa tidak boleh pak?" tanya Ayu penasaran. pak Prabu diam lama, seperti sudah mempersiapkan jawaban namun ia enggan mengatakanya.

(13) Malam semakin gelap, dan hutan semakin sunyi sepi, namun, kata orang, dimana sunyi dan sepi di temui, disana, rahasia di jaga rapat-rapat. Itu yang pertama kali di pikirkan Widya, atau mungkin serombongan orang.

di setiap Nisan, di tutup oleh kain hitam. "ngapunten pak, niki nopo nggih kok" (mohon maaf pak, ini kenapa ya kok)

belum selesai Widya bicara, pak Prabu memotongnya "saya tau, apa yang adik mau katakan, pasti mau tanya, kok patek (nisan) nya, di tutupi pakai kain, gitu to?" Widya mengangguk. rombongan menatap serius pak Prabu, terkecuali Wahyu dan Anton, terdengar mereka sayup tertawa kecil "ini itu namanya, Sangkarso. kepercayaan orang sini. jadi biar tahu, kalau ini loh pemakaman" terang pak Prabu, yang jawabanya sama sekali tidak membuat serombongan anak puas.... (Thread Twitter KDDP, 2019)

Pada kutipan (12), narasi menggiring pembaca pada sesuatu peristiwa yang dianggap paling menakutkan. Peristiwa tersebut bermula pada ketidaktahuan tokoh pada sesuatu yang dilihatnya, yaitu sebuah tempat yang terdapat kain merah dan diikat janur kuning. Hal tersebut berkaitan pada rasa penasaran tokoh dan tidak didapatkannya sebuah jawaban yang memuaskan sehingga menjadikan kepenuhan narasi perlu dicari melalui peristiwa-peristiwa selanjutnya. Pada kutipan (13), ketidaktahuan diciptakan bukan melalui tokoh lain, tetapi pada "kata orang" yang juga tidak diketahui siapa dan dari mana asal-usulnya. Sementara itu, pada kutipan (14), pertanyaanpertanyaan yang pada peristiwa-peristiwa sebelumnya belum terjawab kembali mendapat jawaban yang justru tidak menjawab ketidaktahuan tokoh. Dalam hal ini, ketiga kutipan tersebut menggunakan disnarasi sebagai strategi untuk menemukan keutuhan narasi di dalam teks. Hal tersebut membuat pembaca terbenam ke dalam ketidakutuhan peristiwa sehingga pembaca mengakumulasi ketidakutuhan tersebut sebagai proses pembentukan eventfulness.

Melalui pernyataan-pernyataan di atas, ketidakutuhan narasi menjadi salah satu unsur dalam proses pembentukan eventfulness. Disnarasi pada setiap peristiwa mengakibatkan pembaca terlibat secara penuh dalam menelusuri enigma di dalam teks. Dalam hal ini, dapat dipahami bahwa keterlibatan pembaca dalam teks berakar pada fantasi atas kepenuhan narasi terhadap disnarasi tersebut. Fantasi atas kepenuhan narasi itulah yang menjaga keberjarakan dunia pembaca pada dunia fiksi. Keberjarakan tersebut tidak hanya dilihat dari seberapa jauh kesenjangan antara dunia pembaca dengan dunia fiksi, melainkan sebuah hubungan yang resiprokal dalam menangguhkan jarak. Intensitas dari hubungan resiprokal tersebut menjadikan disnarasi sebagai transportasi pembaca dalam mendapatkan kepe- 
nuhperistiwaan atas cerita.

Berdasarkan uraian di atas, ketiga unsur evaluative devices yang telah dijelaskan merupakan rangkaian eventfulness dalam membentuk kesatuan sensitivitas-konteks. Refleksi antartokoh pada sebuah peristiwa yang ganjil, eventfulness hadir melalui rekonstruksi dari keganjilan peristiwa tersebut. Pada repetisi setiap peristiwa dalam teks, sebuah keganjilan dinaturalisasi sebagai proses identifikasi. Sementara itu, disnarasi menangguhkan keberjarakan antara dunia pembaca dengan dunia fiksi. Dengan demikian, dapat disimpulkan bahwa sensitivitaskonteks merupakan rangkaian eventfulness yang membuat identifikasi terus-menerus terjadi pada peristiwa ganjil sehingga keberjarakan pembaca dengan dunia fiksi tetap terjaga. Keganjilan-keganjilan tersebut merupakan penyimpangan-penyimpangan pada normalitas dan kanonisitas sehingga eventfulness menjadi sensitivitas-konteks dalam cerita $K D D P$.

\section{Transformasi Media: Dari Nonliterasi Menuju Literasi}

Media twitter yang berbasis internet mendukung cerita KDDP sebagai sastra siber yang populer karena penciptaan dan penyebarannya cenderung mudah serta didukung gaya bercerita yang fleksibel. Menurut Murthy (2013: 8), twitter merupakan media berbasis internet yang terdiri dari pesan pendek. Sementara itu, internet-basis untuk mengakses twitter-tidak hanya sebagai medium untuk mentransformasikan informasi, tetapi juga merepresentasikan sesuatu yang tidak bisa direpresentasikan di media lain, misalnya buku. ${ }^{8}$ Melalui hal tersebut, sebagai cerita populer, KDDP menuai berbagai respons dari pembaca sehingga mengundang atensi untuk mereproduksi cerita tersebut ke media lain. Salah satu media yang mereproduksi cerita tersebut ialah media cetak yang berupa novel. Dalam hal ini, cerita KDDP yang berupa thread twitter direproduksi ke dalam bentuk novel pada September 2019.

Transformasi dari media siber ke dalam media cetak merupakan sebuah pergerakan dari nonliterasi menuju literasi. Hal tersebut membuat cerita KDDP yang berasal dari thread twitter mengalami konsekuensi-konsekuensinya dalam sebuah tatanan literasi. Menurut Hirsch (1987: viii), literasi di satu sisi merupakan sebuah pekerjaan yang sangat beragam, tetapi di sisi lain, tatanan literasi menyoroti upaya yang gigih dalam membatasi apa saja yang dianggap "literasi" dan "nonliterasi". Dalam pengklasifikasian tersebut, literasi digerakkan oleh sebuah sistem besar dari industri kapitalisme yang berbuah pada apa yang disebut oleh Anderson (1991: 40) sebagai print-capitalism; cara untuk menciptakan teks baru dengan tujuan meraih pembaca yang lebih luas dan pundi-pundi kapital. Dalam praktiknya, kehadiran printcapitalism tersebut menciptakan dikotomi pada literasi dengan nonliterasi, formal dengan informal, tulisan dengan lisan, dan modern dengan tradisional.

Dikotomi yang diciptakan oleh tatanan literasi menjadi penyebab adanya standardisasi media-sastra siber menuju sastra cetak. Sebagai sastra cetak, novel KDDP mendapat konsekuensi dari literasi nasional. Selain itu, 
literasi dikendalikan oleh sebuah kekuasaan dari agenda kapitalisme. Dalam hal ini, nasionalisme dijadikan alat untuk memproduksi nilai dan mengonstruksi identitas dalam sebuah industri ekonomi modern. Mengutip kalimat dari Gellner (1983: 36), industri ekonomi modern mewajibkan regulasi nasionalisme-sebuah organisasi dari kelompok-kelompok manusia yang berkembang luas, teredukasi secara sentral, dan memiliki budaya yang homogen.

Thread twitter KDDP mengalami perubahan bentuk narasi ketika bertransformasi menjadi novel. Hal tersebut dapat diidentifikasi melalui penggunaan struktur kalimat dan gaya bahasa. Pertama, narasi dalam thread twitter memperlihatkan fleksibilitas penggunaan bahasa berupa kalimat tidak lengkap, kalimat majemuk bertingkat, serta ketidakbakuan penggunaan tanda baca dan ejaan. Sementara itu, penarasian dalam novel memperlihatkan sebuah keteraturan dalam membentuk kalimat serta memfungsikan tanda baca dan ejaan. Perbedaan tersebut dapat dilihat melalui kutipan berikut ini.

"Malam semakin gelap, dan hutan semakin sunyi sepi, namun, kata orang, dimana sunyi dan sepi di temui, disana, rahasia di jaga rapat-rapat. apa ada yang sedang mengadakan hajatan di dekat sini."

(Thread Twitter KDDP, 2019)

"Hari sudah mulai petang. Dari celah-celah pohon di kiri-kanan,Widya bisa melihat pemandangan menakjubkan sekaligus sedikit mengerikan."

"Satu yang menjadi pertanyaannya, di mana hajatan yang ia pikir diadakan di desa itu?"

(Simpleman, 2019: 19)

Kutipan-kutipan di atas menunjukkan konsekuensi yang ditempuh oleh KDDP dalam transformasinya menuju literasi, yakni formalisasi bahasa. Transformasi dari infor- malitas menuju formalitas merupakan suatu bentuk kuasa negara dalam mengatur literasi. Dalam menjalankan kekuasaannya, negara melakukan standardisasi bahasa melalui aparatusnya yang berbentuk Kamus Besar Bahasa Indonesia dan Pedoman Umum Ejaan Bahasa Indonesia. Dalam literasi, eksistensi negara diwakili oleh aturan-aturan dari Badan Pengembangan Bahasa dan Perbukuan. Hal tersebut diasumsikan sebagai aspek yang melatarbelakangi formalisasi bahasa pada teks dari thread twitter ke dalam novel. Implikasi dari formalisasi atau standardisasi tersebut adalah tunduknya teks KDDP pada kuasa negara dalam meraih kapital pada literasi nasional. ${ }^{9}$ Di sanalah, teks KDDP nyatanya tidak dapat berkutik dalam arus print-capitalism.

Formalisasi berupa kosakata, ejaan, dan ragam dalam gaya bahasa teks KDDP dari thread twitter ke novel bertujuan untuk memperluas target pembaca dengan kepentingan meraih kapital. Hal tersebut menimbulkan dampak positif dan negatif dalam segi narasi. Dampak positif dari formalisasi teks dalam literasi ialah keteraturan dan konsistensi penggunaan bahasa Indonesia dalam menarasikan teks sehingga memperkecil kemungkinan ambiguitas atau ketaksaan. Dalam konteks nasional, cerita dapat dinikmati dan dipahami oleh seluruh masyarakat Indonesia karena cerita KDDP dalam thread twitter menggunakan diksi yang didominasi oleh bahasa Jawa. Misalnya, orang yang berasal dari etnis selain Jawa dapat menikmati cerita KDDP di dalam novel karena telah melalui proses alih dan formalisasi bahasa tanpa harus membuka kamus atau mencari definisi-definisi di luar teks. Selain berdam- 
Poetika: Jurnal Ilmu Sastra

Vol. VII No. 2, Desember 2019

pak positif, formalisasi bahasa teks $K D D P$ ke dalam bentuk literasi menimbulkan dampak negatif, yakni teks menjadi kurang luwes dan kehilangan identitasnya karena telah disesuaikan oleh standardisasi berupa kosakata, struktur kalimat bahasa, dan gaya bahasa. Hal tersebut mengakibatkan bentuk literasi yang diusung negara terkesan homogen dan tidak banyak varian sehingga perkembangan bentuk karya sastra dalam literasi justru mengalami keterbatasan pada identitas yang tunggal.

\section{Transformasi Puitika}

Selain formalisasi bahasa, masuknya teks $K D D P$ dalam zona literasi mengakibatkan transformasi puitika. Dalam hal ini, akan dilihat bagaimana pengaruh dari kuasa literasi terhadap puitika teks pada novel KDDP.

Seperti yang telah dibahas pada bagian sebelumnya, eventfulness merupakan aspek yang menentukan kepopuleran cerita KDDP. Akan tetapi, dalam dua media yang disoroti pada penelitian ini, yakni thread twitter dan novel, masing-masing media memiliki bentuk puitika yang berbeda dalam menciptakan sebuah peristiwa yang berkaitan dengan pembangunan eventfulness. Dalam peristiwa pada kutipan (1) dan (2), pengarang mendeskripsikan peristiwa suara gamelan melalui tiga refleksi tokoh, yaitu tokoh Widya, Nur, dan Ayu. Akan tetapi, dalam narasi novel, pengarang mendeskripsikan peristiwa tersebut dengan menambahkan satu refleksi tokoh, yaitu tokoh Pak Prabu. Hal tersebut tergambar melalui kutipan berikut.
DOI 10.22146/poetika.51571

ISSN 2338-5383 (print); 2503-4642 (online)

(i) Tidak ada desa lain di sini, Mbak, hanya desa ini. Mungkin Mbak cuma krunguen (kedengaran) jadi gak usah terlalu dipikirkan ya, mbak. Mari saya antar ke rumah yang akan kalian jadikan tempat selama di desa kami," kata Pak Prabu. Ia tersenyum kepada Widya, mencoba menghapus rasa penasaran yang mengganjalnya (Simpleman, 2019: 22).

Melalui kutipan (i) tersebut, penambahan deskripsi yang dilakukan pengarang melalui refleksi tokoh Pak Prabu justru menaturalisasi peristiwa suara gamelan. Dapat dipahami bahwa penambahan deskripsi pada peristiwa terdengarnya suara gamelan dalam novel semakin menghilangkan konstruksi hal mistis yang telah tercipta di dalam thread twitter. Sementara itu, identifikasi objek hantu pada kutipan (11) yang terbangun melalui repetisi peristiwa menari justru mengalami kekaburan identifikasi objek hantu melalui narasi dalam novel. Hal tersebut tergambar melalui kutipan novel berikut ini.

(ii) Nak, sebenarnya ada yang harus kamu ketahui tentang desa ini, salah satunya, aturan dasar desa ini. Desa ini dulu dikenal dengan nama desa penari, sebuah desa yang banyak melahirkan penari-penari yang sudah terkenal di daerah ini. Kamu tahu Sinden kolam yang prokernya sedang kamu kerjakan? Sebenarnya nama Sinden itu, adalah Sinden Kembar." (iii) Iya, Sinden Kembar. Ada kolam serupa, tapi kolam itu sengaja disembunyikan karena dihuni oleh sosok makhluk yang sudah lama tinggal di hutan ini, namanya Badarawuhi, Ratu Ular Kidul," ucap Mbah Buyut, sembari menatap Widya nanar

(Simpleman, 2019: 116-117).

Berdasarkan kutipan (ii) dan (iii) tersebut, pendeskripsian objek hantu dinarasikan lebih panjang dan lengkap. Di dalam thread twitter, objek hantu yang diidentifikasi melalui repetisi peristiwa ialah seorang penari. Akan tetapi, di dalam novel, objek hantu tidak dideskripsikan sebagai seorang penari sehingga objek hantu gagal diidentifikasi menjadi subjek hantu. Da- 
Poetika: Jurnal Ilmu Sastra

Vol. VII No. 2, Desember 2019

lam novel, pengarang menarasikan bahwa Badarawuhi ialah seorang Ratu Ular Kidul bukan seorang penari yang peristiwanya direpetisi sebagai proses identifikasi. Dengan demikian, objek hantu di dalam novel gagal diidentifikasi melalui pembangunan eventfulness sehingga mengurangi keterbenaman pembaca di dalam teks.

Selain perbedaan refleksi tokoh dan repetisi peristiwa, terdapat pula perbedaan strategi puitika antara thread twitter yang sengaja didisnarasikan dengan novel yang dinarasikan secara utuh. Perbedaan tersebut dapat dilihat melalui kutipan berikut.

(15) sebelumnya, penulis tidak mendapat ijin untuk memposting cerita ini dari yang empunya cerita, karena beliau memiliki ketakutan sendiri pada beberapa hal, yang meliputi kampus, dan desa tempat KKN di adakan.

(16) sampailah mereka di Desa $\mathrm{W}^{* * * *}$, tempat mereka akan mengabdikan diri selama 6 minggu ke depan.

(17) "mboten mas. berhenti di jalur Alas D engken enten sing jemput" (tidak mas, nanti berhenti di jalur hutan D, nanti ada yang jemput) sahut Nur

(Thread Twitter KDDP, 2019).

Pada awal thread twitter, pengarang melalui sudut pandang orang pertama mendeskripsikan bahwa latar tempat di cerita KDDP sengaja dirahasiakan atau didisnarasikan. Namun demikian, berbeda halnya dengan novel. Dalam novel, pengarang menarasikan latar tempat cerita secara jelas sehingga membuat pembaca tidak bebas dalam menginterpretasi latar cerita tersebut, seperti kutipan berikut ini.

(iv) "Iya, Bu," jawab Widya mantap. Saat ini, Widya menjalankan tugasnya sebagai mahasiswi semester akhir, di sebuah universitas Jawa Timur.

(v) Setelah semua siap, mobil melaju menuju tempat di mana mereka nanti akan tinggal, di sebuah desa di pelosok Jawa.

(vi) Orang bilang, hutan ini hutan paling angker di
DOI 10.22146/poetika.51571

ISSN 2338-5383 (print); 2503-4642 (online)

Jawa Timur

(Simpleman, 2019: 3, 9, dan 11).

Berdasarkan kutipan-kutipan di atas, terdapat perbedaan pendeskripsian latar tempat. Dalam thread twitter, latar tempat dideskripsikan menggunakan inisial huruf pertama yang bertujuan untuk pendisnarasian latar cerita di dalam teks. Sementara itu, dalam novel, latar tempat dideskripsikan secara jelas berdasarkan letak geografis, yaitu daerah Jawa Timur. Perbedaan tersebut menyebabkan pergeseran puitika dalam melakukan disnarasi. Selain itu, disnarasi dalam thread twitter juga berbentuk gaya bercerita melalui sudut pandang orang pertama, seperti contoh berikut.

Malam ini, gw akan bercerita sebuah cerita dari seseorang, yang menurut gw spesial. kenapa? karena gw sedikit gak yakin bakal bisa menceritakan setiap detail apa yang beliau alami, sebuah cerita tentang pengalaman beliau selama KKN, di sebuah desa penari."

"sebelum gw memulai semuanya. gw sedikit mau menyampaikan beberapa hal."

"sebelumnya, penulis tidak mendapat ijin untuk memposting cerita ini dari yang empunya cerita, karena beliau memiliki ketakutan sendiri pada beberapa hal, yang meliputi kampus, dan desa tempat KKN di adakan."

"tetapi, karena penulis berpikir bahwa cerita ini memiliki banyak pelajaran yang mungkin bisa dipetik terlepas dari pengalaman sang pemilik cerita akhirnya, kami sepakat, bahwa, semua yang berhubungan dengan cerita ini, meliputi nama kampus, fakultas, Desa dan latar cerita, akan sangat di rahasiakan."

"jadi buat teman-teman yang membaca cerita ini, yang mungkin tahu, atau merasa familiar dengan beberapa tempat yang meski di samarkan ini, di mohon, untuk diam saja, atau merahasiakan semuanya, karena ini sudah menjadi janji penulis dan pemilik cerita

(Thread Twitter KDDP, 2019).

Gaya penarasian melalui sudut pandang orang pertama tersebut mengesankan komunikasi dua arah antara penulis dengan pembaca. Hal tersebut meleburkan posisi antara 
dunia fiksi di dalam teks dan dunia pembaca. Konstruksi narasi tersebut dibangun melalui dua arah sehingga pembaca hadir di dalam teks dan terbenam dalam eventfulness yang dibangun oleh dunia fiksi. Selain itu, gaya bercerita tersebut mengaburkan antara yang fiksi dan fakta sehingga pembaca tenggelam ke dalam cerita karena menganggap kisah dalam teks tersebut adalah nyata. Sementara itu, di dalam novel, gaya bercerita tersebut dihilangkan karena dampak dari formalisasi bahasa yang mereduksi gaya sastra lisan pada sastra cetak.

Twitter merupakan media yang memfasilitasi adanya praktik sastra lisan di era modern.10 Melalui twitter, penulis dan pembaca terlibat dalam percakapan yang interaktif pada peristiwa di setiap thread. Menurut Wharton (via Manguel, 1983: xvi-xix), kesuksesan sebuah fiksi ditentukan oleh standar kualitas yang terletak pada sesuatu yang tidak perlu dianggap serius, tetapi dialami sangat serius, setidaknya dalam durasi penarasian. Dalam konteks ini, narasi dalam thread twitter menyajikan peristiwa yang sebelumnya tidak dianggap serius, tetapi ketika terdapat percakapan yang interaktif, peristiwa dalam thread twitter menjadi dialami secara serius.

Gaya bercerita dari thread twitter KDDP dapat dilihat sebagai praktik sastra lisan. Sastra lisan memiliki ciri yang lebih bebas daripada sastra cetak. Sastra lisan tidak terpaku pada bentuk kaidah bahasa formal. Dilihat dari kutipan di atas, pencerita menarasikan sebuah cerita dari empunya cerita yang tidak disebutkan namanya, yang merupakan strategi dalam memberi jarak antara pencerita dengan sumber cerita. Otoritas di dalam teks menjadi kabur sehingga teks menjadi sebuah ruang terbuka untuk diinterpretasikan oleh pembaca dan pencerita tersebut. Akan tetapi, hal tersebut dihilangkan ketika teks dalam twitter bertransformasi menjadi novel. Teks KDDP yang sebelumnya merupakan kanon terbuka menjadi kanon tertutup yang tidak dapat diinterupsi dan membatasi interpretasi. Dari fenomena tersebut dapat dilihat sebagai implikasi dari terciptanya sebuah sekat antara tradisi lisan dan tradisi tulis sebagai konsekuensi masuknya teks KDDP ke dalam zona literasi. 11

Perbedaan rangkaian eventfulness yang terjadi antara thread twitter dengan novel tersebut membuat degradasi puitika di dalam teks KDDP. Transformasi media berdampak pada transformasi puitika sehingga keterbenaman pembaca terhadap dunia fiksi dalam novel mengalami degradasi. Hal tersebut menyebabkan keberjarakan pembaca dengan dunia fiksi menjadi semakin luas sehingga pembaca tidak merasakan sensitivitas-konteks di dalam eventfulness cerita. Dengan demikian, dapat dipahami bahwa transformasi puitika melalui transformasi media menjadikan cerita KDDP kehilangan kesan mistis. Meskipun demikian, transformasi puitika tidak serta-merta disengaja oleh pengarang, tetapi media yang berbeda memiliki aturan-aturan yang berbeda pula. Media cetak, seperti novel, memiliki aturan-aturan yang membuat cerita KDDP yang awalnya cerita lisan yang dituliskan melalui thread twitter, menjadi sebuah literasi. Alih-alih menyempurnakan cerita KDDP melalui formalisasi bahasa, 
print-capitalism justru mendegradasi eventfulness dalam pembentukan sensitivitas-konteks sehingga dunia pembaca tidak melebur dengan bangunan dunia fiksi.

\section{Simpulan}

Cerita KDDP merupakan cerita populer karena keberadaannya mengundang banyak atensi, terutama para pengguna media sosial twitter. Hal tersebut sekaligus menjadikan cerita $K D D P$ sebagai sastra siber karena penciptaan dan penyebarannya cenderung mudah serta tidak menuntut narasi yang panjang. Sebagai karya sastra bergenre horor, cerita KDDP mempunyai strategi puitika yang menguatkan eventfulness cerita sehingga membuat pembaca menjadi terbenam dalam dunia fiksi. Akan tetapi, puitika dalam thread twitter KDDP mengalami degradasi ketika cerita ditransformasikan menjadi sebuah novel yang termasuk dalam zona literasi. Print-capitalism merupakan salah satu faktor yang mendegradasi puitika KDDP sekaligus mengubah identitas teks.

Sensitivitas-konteks dalam cerita KDDP berangkat dari puitika pembenaman pada teks. Sebagai alat ukur, evaluative devices digunakan untuk menyelisik unsur-unsur eventfulness dalam cerita yang menciptakan sensitivitas-konteks. Pertama, dapat diidentifikasikan perbedaan refleksi-refleksi antartokoh dalam menjelaskan peristiwa ganjil yang semakin mengukuhkan keganjilan. Dalam hal ini, keganjilan tersebut bersumber dari multirefleksi yang merekonstruksi alienasi tokoh pada suatu peristiwa, yakni terdengarnya suara gamelan dan mun- culnya sosok penari. Perbedaan refleksi antartokoh atas peristiwa tersebut memunculkan kemistisan yang mendukung eksistensi objek hantu sehingga pembaca dapat merasakan kemistisannya. Kedua, repetisi peristiwa menari dalam cerita KDDP mengindikasikan progres dari identifikasi objek hantu yang natural menjadi subjek yang unnatural. Ketiga, ditemukan disnarasi pada setiap peristiwa dalam cerita $K D D P$ yang mengakibatkan pembaca terlibat secara penuh dalam menelusuri enigma di dalam teks.

Kepopuleran cerita $K D D P$ menjadi faktor yang menyebabkannya mengalami transformasi media, dari thread twitter menjadi novel. Transformasi media tersebut merupakan sastra siber menjadi sastra cetak. Sebagai sastra cetak, novel KDDP mendapat konsekuensi dari zona literasi nasional yang berupa print-capitalism. Konsekuensi tersebut antara lain, formalisasi bahasa dan transformasi identitas dari lokalisme Jawa menjadi nasionalisme. Keterlibatan cerita KDDP pada zona literasi berdampak pada transformasi puitika pada teks. Melalui evaluative device, ditemukan bahwa novel KDDP mengalami degradasi puitika dari teks aslinya di dalam thread twitter. Hal tersebut mengakibatkan kegagalan dalam membangun sensitivitaskonteks karena melemahnya konstruksi eventfulness dalam novel. Dengan demikian, dapat disimpulkan bahwa degradasi puitika dalam teks $K D D P$ disebabkan oleh masuknya $K D D P$ ke dalam zona literasi yang berkonsekuensi terhadap perubahan bentuk dan identitas di dalam teks. Dari fenomena tersebut, dapat dilihat bahwa agenda dari print-capitalism telah mendekstruksi kreativitas di dalam karya sastra. 
Poetika: Jurnal Ilmu Sastra

Vol. VII No. 2, Desember 2019

\section{Catatan}

1. Nama akun ini merupakan nama yang telah diganti dari @Simpleman. Perubahan nama tersebut diakses melalui akun twitter pada tanggal 24 Oktober 2019, pukul 23.09 WIB.

2. Twitter merupakan sebuah ruang atau platform yang dapat disebut sebagai jejaring sosial (Gillespie, 2010; Wittel, 2001). Twitter juga dapat dilihat sebagai media yang dangkal, dalam artian lebih berisi isu-isu terkini, populer, dan bersifat temporal (Weller, 2014).

3. Bolter dan Grusin (1998) menjelaskan fungsi remediasi dalam transisi intermedia dalam teks sebagai refesyen dari media sebelumnya untuk menjawab tantangan pada media yang baru atau lainnya.

4. KKN (Kuliah Kerja Nyata) dilakukan oleh mahasiswa/mahasiswi pada tingkat akhir yang bertujuan untuk mengabdi kepada masyarakat.

5. Menurut Bourdieu (1996), fiksi populer harus memiliki nilai objektif dan masif sebagai fungsinya untuk meraih pasar dalam produksi skala besar; hal tersebut menyangkut dengan peraihan kuantitas pembaca.

6. Hal tersebut diungkapkan David Silverman pada bukunya yang berjudul Qualitative Research: Theory, Method and Practice (1997).

7. Carroll (1990) thus upholds the original meaning of a monster; it is there to demonstr-ate something

8. Tulisan artikel oleh Matthew Griffin "Literary Studies +/- Literature: Friedrich A. Kittler's Media Histories" dalam jurnal New Literary History, Vol. 27, No. 4, 1996.

9. Bourdieu (2007) mengungkapkan bahwa dalam habitusnya, karya sastra berusaha meraih berbagai bentuk kapital yang di dalamnya terdapat ekonomi, sosial, dan budaya.

10. Dalam buku The Post-colonial Studies
DOI 10.22146/poetika.51571

ISSN 2338-5383 (print); 2503-4642 (online)

Reader (2006), oralitas atau kelisanan hanya dapat eksis ketika memberikan maknanya melalui respons secara langsung. Hal tersebut hanya dapat diperoleh melalui percakapan yang interaktif pada keutuhan percakapan atau perpindahan peristiwa.

11. Heath (1983) mengatakan bahwa peristiwa literasi menciptakan sebuah dikotomi yang membatasi tradisi oral dengan tradisi tulis. Secara tidak sadar, literasi mengontekstualisasi dan membentuk makna dalam perjumpaannya pada teks.

\section{Daftar Pustaka}

Anderson, B. 1991. Imagined Communities: Reflections on the Origin and Spread of $\mathrm{Na}$ tionalism. London: Verso.

Ashcroft, Bill dkk. 2006. The Post-Colonial Studies Reader. New York: Routledge.

Bolter, J. D., dan R. A. Grusin. 1998. Remediation: Understanding New Media. Cambridge: MIT Press.

Bourdieu, P. 1996. The Rules of Art: Genesis and Structure of the Literary Field. Stanford: Stanford University Press. 2007. "The Forms of Capital". Dalam A. R. Sadovnic, The Sociology of Education. New York: Routledge.

Brümmer, Gero. 2016. "Of Minds and Monsters: The Eventfulness of Monstrosity and the Poetics of Immersion in Horror Literature". Esai dalam Narrative Theory, Literature, and New Media. London: Routledge.

Carroll, Noel. 1990. The Philosophy of Horror or Paradoxes of the Heart. New York: Routledge.

Collins, James dan Richard K. Blot. 2003. Literacy and Literacies: Text, Power, and Identity. New York: Cambridge University Press.

Faris, W. B. dan Parkinson Zamora. 1995. Magical Realism: Theory, History, Community. London: Duke University.

Faris, W. B. 2004. Ordinary Enchantments Magical Realism and the Remystification of Narrative. Nashville: Vanderbilt University Press.

Gellner, E. 1983. Nations and Nationalism. Itha- 
ca, NY: Cornell University Press.

Gillespie, T. 2010. "The Politic of Platforms". Jurnal New Media \& Society, Vol. 12, No. 3.

Griffin, Matthew. 1996. "Literary Studies +/Literature: Friedrich A. Kittler's Media Histories" dalam jurnal New Literary History, Vol. 27, No. 4.

Heath, S. B. 1983. Ways with Words: Language, Life, and Work in Communities and Classrooms. New York: Cambridge University Press.

Hirsch, E. 1987. Cultural Literacy: What Every American Needs to Know. Boston: Houghton Mifflin.

Hogan, Patrick. 2013. Ulysses and the Poetics of Cognition. London: Routledge.

Kittler, Friedrich. 1986. A Discourse on Discourse. Stanford: Stanford Literature Review.

Manguel, Alberto. 1983. Black Water: The Anthology of Fantastic Literature. London: Picador.

McLuhan, Marshall. 1967. The Medium Is the Message: An Inventory of Effects. New York.

Murthy, Dhiraj. 2013. Twitter: Digital Media and Society Series. Cambridge: Polity Press.
Prince, Gerald. 2008. "Narrativehood, Narrativeness, Narrativity, Narratability." In Theorizing Narrativity. Berlin: Walter de Gruyter.

Silverman, David. 1997. Qualitative Research: Theory, Method and Practice. London: Sage Publications.

Simpleman. 2019. KKN di Desa Penari. Jakarta: Bukune Kreatif Cipta.

Weller, Katrin (ed). 2014. Twitter and Society. New York: Peter Lang.

Williams, Raymond. 1985. Keywords: A Vocabulary of Culture and Society. London: Oxford University Press.

Wittel, A. 2001. "Toward a Network Sociality". Esai dalam Theory, Culture \& Society, Vol. 18, No. 6.

\section{Daftar Laman}

https://threadreaderapp.com/ thread/1143116541480726531.html diakses pada 24 Oktober 2019. 23.09 WIB.

https://threadreaderapp.com/ thread/1152570021282844673.html diakses pada 24 Oktober 2019. 23.09 WIB. 